\title{
Studies of the Mechanism by Which Chronic Metabolic Acidosis Augments Urinary Calcium Excretion in Man*
}

\author{
Jacob Lemann, JR., $\dagger$ John R. Litzow, and Edward J. Lennon with the \\ TECH NiCAL assistance of Opal A. Kelly
}

(From the Department of Medicine and the Clinical Research Center, Marquette University School of Medicine and Milwaukee County General Hospital, Milwankee, Wis.)

\begin{abstract}
Summary. We carried out clearance studies in nine healthy adults and four patients with hypoparathyroidism before and after inducing stable metabolic acidosis with either $\mathrm{NH}_{4} \mathrm{Cl}$ or acetazolamide. Clearances were repeated in seven normal subjects and three of the patients 3 days after stopping these agents.

During acidosis in the normal subjects, serum ultrafilterable calcium concentration rose significantly, but inulin clearance fell to a greater extent, so that the calculated filtered load of calcium fell significantly. Despite this, urinary calcium excretion rose. Urinary calcium excretion remained elevated in the recovery studies when the serum ultrafilterable calcium concentration and filtered load of calcium had returned to control levels. Evidence is presented indicating that the increased calcium excretion which occurred during acidosis and recovery clearances was not due to natriuresis or to increased excretion of complexing anions. The comparable results in the four patients with hypoparathyroidism, two of whom also had hypothyroidism, suggest that the capacity to alter secretion rates of parathyroid hormone, thyrocalcitonin or both is not a critical determinant of the augmented rates of calcium excretion during acidosis.

We conclude that metabolic acidosis produces increased urinary calcium excretion by causing decreased renal tubular calcium reabsorption. Evidence is presented which suggests that this is a direct effect of metabolic acidosis on metabolic processes within renal tubular cells.
\end{abstract}

\section{Introduction}

A number of studies have shown that urinary calcium excretion is increased during induced (1-3) or spontaneous (4) metabolic acidosis. In the dog, acute metabolic acidosis appears to cause increased urinary calcium excretion as a result of

\footnotetext{
* SuBmitted for publication January 5, 1967 ; accepted April 20, 1967.

This investigation was supported in part by $U$. S. Public Health Service research grant 5 M01 FR-00058 and in part by U. S. Public Health Service research grant 2 R01 AM-08924.

† Address requests for reprints to Dr. Jacob Lemann, Jr., Dept. of Medicine, Marquette University School of Medicine, Milwaukee County General Hospital, 8700 West Wisconsin Ave., Milwaukee, Wis. 53226.
}

a rise in serum filterable calcium concentration and of the filtered calcium load (5). The mechanism of augmentation of urinary calcium excretion during sustained metabolic acidosis in man has not been elucidated.

To examine this problem, we carried out renal clearance studies in the same healthy adult subjects and in patients with hypoparathyroidism during control conditions, after stable metabolic acidosis was induced with $\mathrm{NH}_{4} \mathrm{Cl}$ or acetazolamide, and on the 3rd recovery day after stopping these agents.

We found that urinary calcium excretion was significantly increased in the normal subjects during stable acidosis despite a significant fall in the 
ACIDOSIS AND CALCIUM EXCRETION

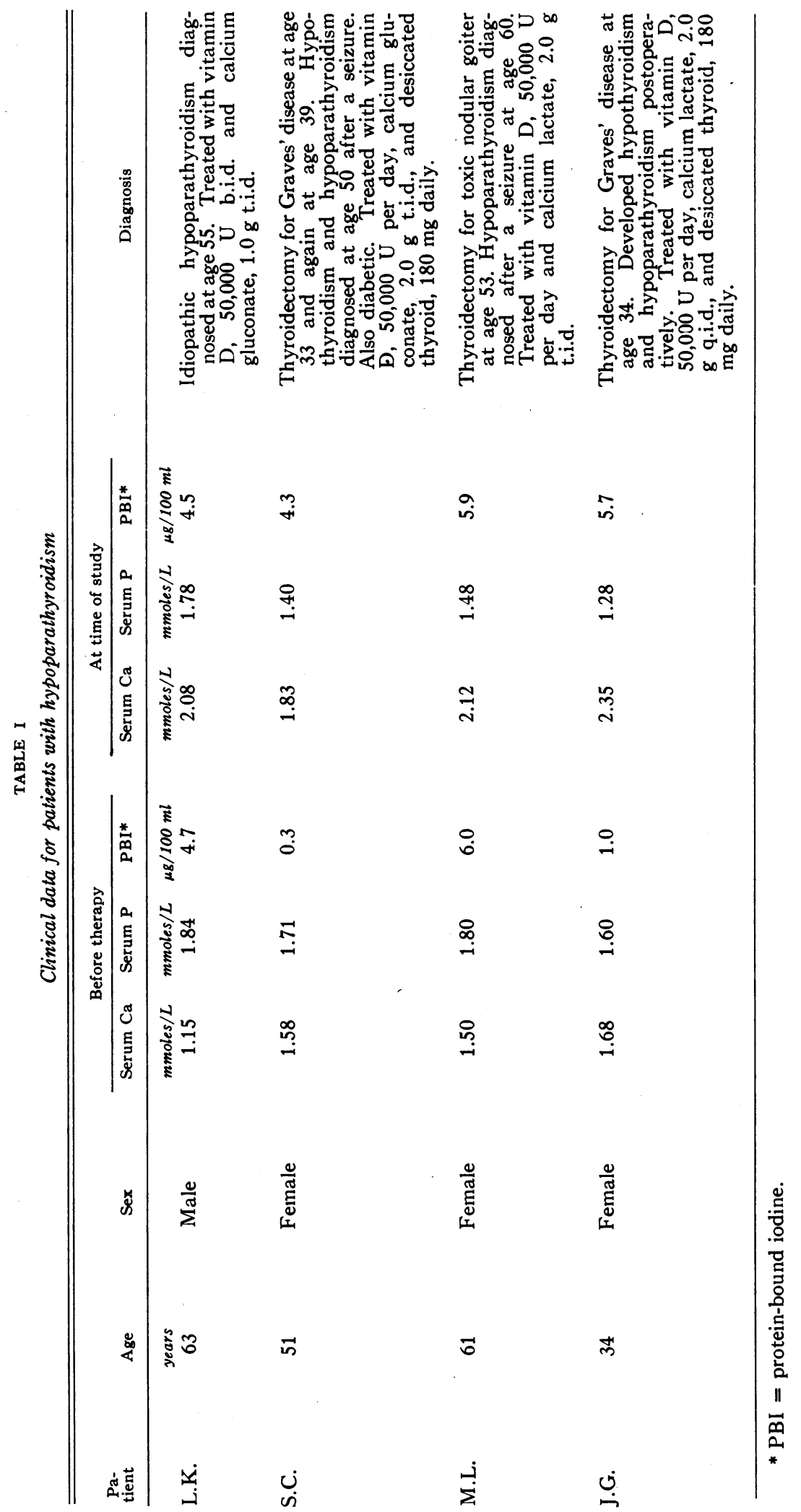


TABLE II

Experimental data for normal subject J. Br.*

\begin{tabular}{|c|c|c|c|c|c|c|c|c|}
\hline $\begin{array}{l}\text { Metabolic } \\
\text { period }\end{array}$ & $\begin{array}{l}\text { Clearance } \\
\text { period }\end{array}$ & $\begin{array}{l}\text { Blood } \\
{\left[\mathrm{H}^{+}\right]}\end{array}$ & $\underset{\left[\mathrm{HCO}_{3}^{-}\right]}{\text {Serum }}$ & $\begin{array}{c}\text { Serum } \\
\text { total }[\mathrm{Ca}]\end{array}$ & $\begin{array}{l}\text { Serum } \\
\text { UF }_{\mathrm{Cs}}\end{array}$ & Cinulin $_{\text {in }}$ & Filtered Ca & $\mathrm{UCaV}_{\mathrm{Ca}}$ \\
\hline \multirow[t]{2}{*}{ Control } & $\begin{array}{l}1 \\
2 \\
3 \\
4\end{array}$ & $\begin{array}{c}n E q / L \\
38.9 \\
\\
38.9\end{array}$ & $\begin{array}{c}m E q / L \\
24.3 \\
\\
\\
24.5\end{array}$ & $\begin{array}{c}\text { mmoles } / L \\
2.40 \\
2.38 \\
2.36 \\
2.37\end{array}$ & $\begin{array}{c}\text { mmoles/L } \\
1.42 \\
1.38 \\
1.44 \\
1.42\end{array}$ & $\begin{array}{c}m l / \min \\
124 \\
117 \\
113 \\
111\end{array}$ & $\begin{array}{c}\text { umoles } / \min \\
176 \\
161 \\
163 \\
158\end{array}$ & $\begin{array}{c}\text { umoles } / \mathrm{min} \\
1.30 \\
0.88 \\
1.03 \\
0.82\end{array}$ \\
\hline & Mean & 38.9 & 24.4 & 2.38 & 1.41 & 116 & 164 & 1.01 \\
\hline \multirow[t]{2}{*}{$\begin{array}{l}\mathrm{NH}_{4} \mathrm{Cl} \\
\text { acidosis }\end{array}$} & $\begin{array}{l}1 \\
2 \\
3 \\
4\end{array}$ & $\begin{array}{l}49.0 \\
52.5\end{array}$ & $\begin{array}{l}16.4 \\
15.6\end{array}$ & $\begin{array}{l}2.28 \\
2.34 \\
2.33 \\
2.35\end{array}$ & $\begin{array}{l}1.42 \\
1.37 \\
1.48 \\
1.41\end{array}$ & $\begin{array}{l}107 \\
123 \\
108 \\
115\end{array}$ & $\begin{array}{l}152 \\
169 \\
160 \\
162\end{array}$ & $\begin{array}{l}5.10 \\
6.55 \\
6.40 \\
5.80\end{array}$ \\
\hline & Mean & 50.8 & 16.0 & 2.32 & 1.42 & 113 & 161 & 5.96 \\
\hline \multirow[t]{2}{*}{ Recovery } & $\begin{array}{l}1 \\
2 \\
3 \\
4\end{array}$ & 35.5 & 27.0 & $\begin{array}{l}2.32 \\
2.32 \\
2.34 \\
2.31\end{array}$ & $\begin{array}{l}1.41 \\
1.46 \\
1.46 \\
1.46\end{array}$ & $\begin{array}{l}118 \\
131 \\
128 \\
131\end{array}$ & $\begin{array}{l}166 \\
191 \\
187 \\
191\end{array}$ & $\begin{array}{l}2.45 \\
2.30 \\
2.45 \\
2.15\end{array}$ \\
\hline & Mean & 36.8 & 26.8 & 2.32 & 1.45 & 127 & 184 & 2.34 \\
\hline
\end{tabular}

* Abbreviations: $\mathrm{UF}_{\mathrm{Ca}}=$ ultrafilterable calcium concentration; $\mathrm{C}_{\mathrm{inulin}}=$ inulin clearance $; \mathrm{U}_{\mathrm{Ca}} \mathrm{V}=$ urinary calcium excretion.

filtered load of calcium. Augmented urinary calcium excretion persisted in the normal subjects during the recovery studies when the filtered load of calcium was at control levels. These results clearly indicate that the augmentation of urinary calcium excretion during experimental chronic metabolic acidosis in normal man is due to decreased tubular calcium reabsorption. This could not be explained by the known effects of sodium excretion (6) or the excretion of poorly reabsorbable complexing anions (7) on urinary calcium excretion. Comparable results in the patients with hypoparathyroidism, two of whom were also hypothyroid, suggest that alterations in the rates of secretion of parathyroid hormone or thyrocalcitonin are not the cause of the augmented urinary calcium excretion.

\section{Methods}

Studies were carried out in nine healthy adults, two patients with hypoparathyroidism, and two patients with both hypoparathyroidism and hypothyroidism. The significant clinical details concerning these patients are shown in Table I. All were receiving adequate replacement therapy when studied. All subjects were hospitalized in the Marquette University School of Medicine Clinical Research Center and received constant normal diets. All clearance studies were begun at 8:00 a.m. after overnight fasting. The subjects drank a liter of water at 7:00 a.m. to induce diuresis and thereafter were given water at intervals in amounts equivalent to urinary losses. After obtaining blood and urine samples for blank determinations, an appropriate priming dose of inulin was injected and thereafter a sustaining infusion of inulin in isotonic saline was given at $3 \mathrm{ml}$ per minute with an infusion pump. After a 45-minute equilibration period, four clearance periods were collected. Blood samples were drawn at the midpoint of each period. The subjects were allowed to stand or sit to void spontaneously, but otherwise remained recumbent during the studies.

After control clearances, metabolic acidosis was induced in six of the normal subjects and in each of the four patients by the daily oral administration of gradually increasing doses of $\mathrm{NH}_{4} \mathrm{Cl}$ for 3 to 4 days, and thereafter of a constant daily dose of $\mathrm{NH}_{4} \mathrm{Cl}$. Clearances were repeated 7 to 11 days after $\mathrm{NH}_{4} \mathrm{Cl}$ was begun when a stable state of acidosis was present as indicated by no further fall in serum bicarbonate concentration during the 2 to 3 days before study. In the other three normal subjects, metabolic acidosis was induced by giving $250 \mathrm{mg}$ of acetazolamide four times a day. In these subjects, clearances were repeated 4 to 6 days after the drug was started. Recovery clearances were carried out in seven of the normal subjects and in three of the patients on the morning of the 3rd day after stopping $\mathrm{NH}_{4} \mathrm{Cl}$ or acetazolamide. No significant symptoms occurred in any of the subjects.

Inulin in deproteinized filtrates of plasma and urine was measured with the autoanalyzer by Earley and Friedler's adaptation (8) of the method of Davidson and Sackner (9). Serum ultrafiltrates were prepared by the method of Toribara, Terepka, and Dewey (10). Since the quantity of calcium which is ultrafilterable varies significantly with the $\mathrm{pH}$ at which the ultrafiltrate is separated (10), we modified their method slightly. We handled the blood 
ACIDOSIS AND CALCIUM EXCRETION

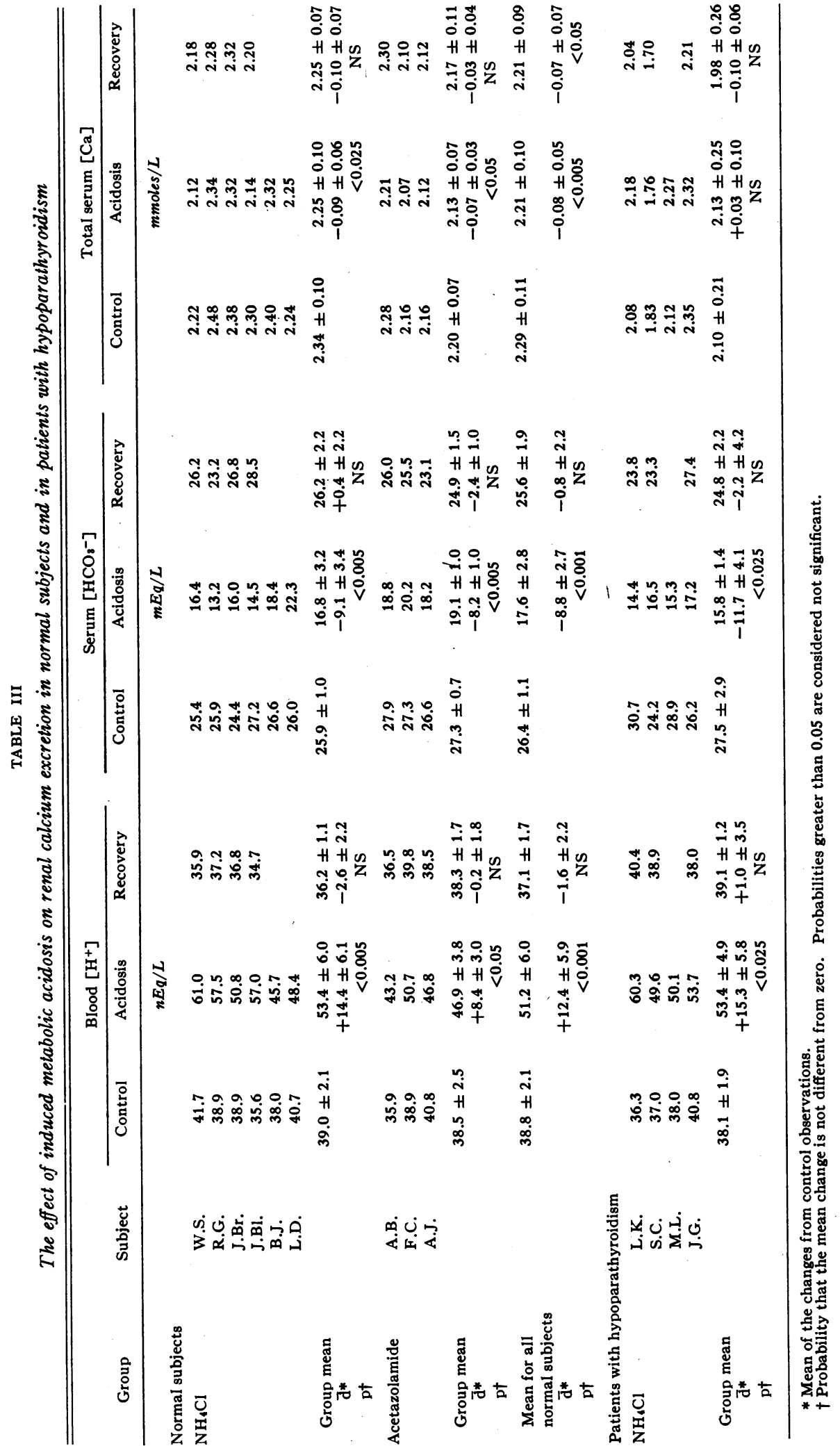




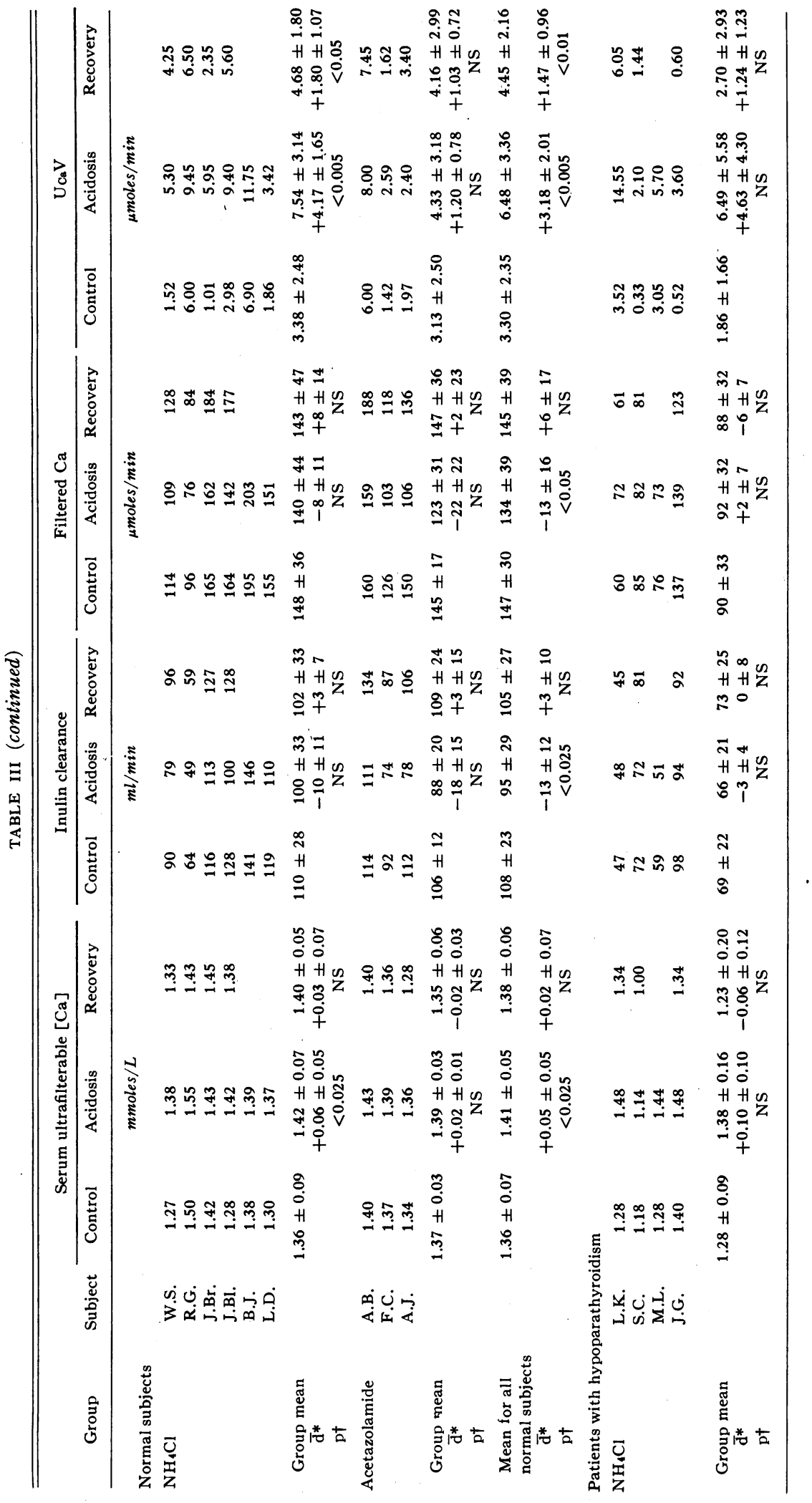


specimens with anaerobic precautions and used a variety of $\mathrm{CO}_{2}$ in air mixtures for gassing the Toribara tubes, allowing a very close approximation to each subject's calculated in vivo $\mathrm{CO}_{2}$ pressure $\left(\mathrm{PcO}_{2}\right)$. With these modifications, it was possible to separate the ultrafiltrate at a $\mathrm{pH}$ within $\pm 0.04 \mathrm{U}$ of that prevailing in vivo.

The remaining methods used in our laboratory have been described in a previous publication (11). The results for each subject are presented as the mean of the four clearance periods in each phase of the studies. Results were evaluated by Student's $t$ test using the equation: $t=(\overline{\mathrm{d}}-0) /(\mathrm{s} / \sqrt{\mathrm{n}})$, where $\overline{\mathrm{d}}$ and $\mathrm{s}$ are the mean and standard deviation of the individual changes from control for the group (12). Thus, each subject served as his own control. All group data are presented as the mean \pm one standard deviation.

\section{Results}

Table II shows in detail the effect of $\mathrm{NH}_{4} \mathrm{Cl}$ acidosis on blood $\left[\mathrm{H}^{+}\right]$, serum $\left[\mathrm{HCO}_{3}^{-}\right]$, and the parameters of renal calcium filtration and excretion in one normal subject $(\mathrm{J}$. Br.). Table III presents the average results of the four clearance periods in each phase of the study of all normal subjects and patients. As illustrated in Table II, the agreement between replicate clearance periods was satisfactory. For all subjects, the coefficient of variation between clearance periods for those parameters required in calculating renal tubular calcium reabsorption averaged the following: inulin clearance $\pm 9.3 \%$, serum ultrafilterable calcium concentration $\pm 2.5 \%$, filtered calcium $\pm 9.5 \%$, and urinary calcium excretion $\pm 9.8 \%$.

All subjects lost weight for a few days because of diuresis after $\mathrm{NH}_{4} \mathrm{Cl}$ or acetazolamide was begun and gained weight for a few days when these agents were stopped. In the control studies, the average body weight of the nine normal subjects was $63.11 \pm 6.05 \mathrm{~kg}$ and of the four patients, $63.34 \pm 11.16 \mathrm{~kg}$. The changes in body weight from control at the time of subsequent clearances for the normal subjects and patients averaged the following: during acidosis, $-1.03 \pm 1.13 \mathrm{~kg}$ and $-1.52 \pm 0.68 \mathrm{~kg}$; during recovery, $-0.05 \pm 1.35$ $\mathrm{kg}$ and $-0.79 \pm 1.03 \mathrm{~kg}$, respectively. During the clearances urine flow rates were always above $8 \mathrm{ml}$ per minute and were comparable in the same subject in each phase of the studies.

In Tables III, IV, and V, few important differences in the responses to acidosis produced by $\mathrm{NH}_{4} \mathrm{Cl}$ or acetazolamide in the normal subjects were noted. The differences that seem signifi- cant will be described, but otherwise the responses of all normal subjects will be considered together.

As shown in Table III, the expected rise in blood $\left[\mathrm{H}^{+}\right]$and fall in serum $\left[\mathrm{HCO}_{3}^{-}\right]$occurred in each subject during the administration of $\mathrm{NH}_{4} \mathrm{Cl}$ or acetazolamide, and these parameters had returned to control values by the time of the recovery clearances. The severity of the acidosis was comparable between groups.

During acidosis, the serum total calcium concentration fell in eight of the nine normal subjects $(\overline{\mathrm{d}}=-0.08 \pm 0.05$ mmoles per $\mathrm{L} ; \mathrm{p}<0.005)$, whereas serum ultrafilterable calcium concentration $\left(\mathrm{UF}_{\mathrm{Ca}}\right)$ rose in each normal subject $(\overline{\mathrm{d}}=$ $+0.05 \pm 0.05$ mmoles per $\mathrm{L} ; \mathrm{p}<0.025)$. However, because inulin clearance was reduced during acidosis in eight of the nine normal subjects $(\overline{\mathrm{d}}=$ $-13 \pm 12 \mathrm{ml}$ per minute; $\mathrm{p}<0.025)$, the calculated rate of calcium filtration fell significantly $(\overline{\mathrm{d}}=-13 \pm 16 \mu$ moles per minute; $\mathrm{p}<0.05)$. Nevertheless, urinary calcium excretion $\left(\mathrm{U}_{\mathrm{Ca}} \mathrm{V}\right)$ rose in each normal subject $(\overline{\mathrm{d}}=+3.18 \pm 2.01$ $\mu$ moles per minute; $\mathrm{p}<0.005)$.

During acidosis, the patients on the average had a small increase in serum total calcium concentration, and in three of the four, $\mathrm{UF}_{\mathrm{Ca}}$ rose $(\overline{\mathrm{d}}=+$ $0.10 \pm 0.10$ mmoles per $L){ }^{1}$ The average fall in filtration rate for the patients $(\overline{\mathrm{d}}=-3 \pm 4 \mathrm{ml}$ per minute) was smaller than that noted in the normal subjects. Consequently, the calculated rate of filtration of calcium rose in two of the four patients. $\mathrm{U}_{\mathrm{Ca}} \mathrm{V}$ rose in each patient $(\overline{\mathrm{d}}=+4.63$ $\pm 4.30 \mu$ moles per minute). The increase in $\mathrm{U}_{\mathrm{Ca}} \mathrm{V}$ occurred despite a fall in calcium filtration rate in S. C. and M. L. and exceeded the small rise in calcium filtration rate in J. G. The striking and equivalent increases in calcium filtration rate and $U_{\mathrm{Ca}} \mathrm{V}$ in $\mathrm{L}$. K., who had severe idiopathic hypoparathyroidism, differed from the findings in all other subjects studied.

During the recovery clearances, $\mathrm{U}_{\mathrm{Ca}} \mathrm{V}$ remained significantly elevated above control values in the seven normal subjects $(\overline{\mathrm{d}}=+1.47 \pm 0.96 \mu$ moles per minute; $p<0.01$ ) despite the return of blood acid-base measurements to normal. In four of these seven studies, because of either a persistent elevation in $U F_{C a}$ or a rise in filtration rate, the

1 The lack of statistical significance for many of the changes observed in the patients clearly results from the small size of the group available for study. 


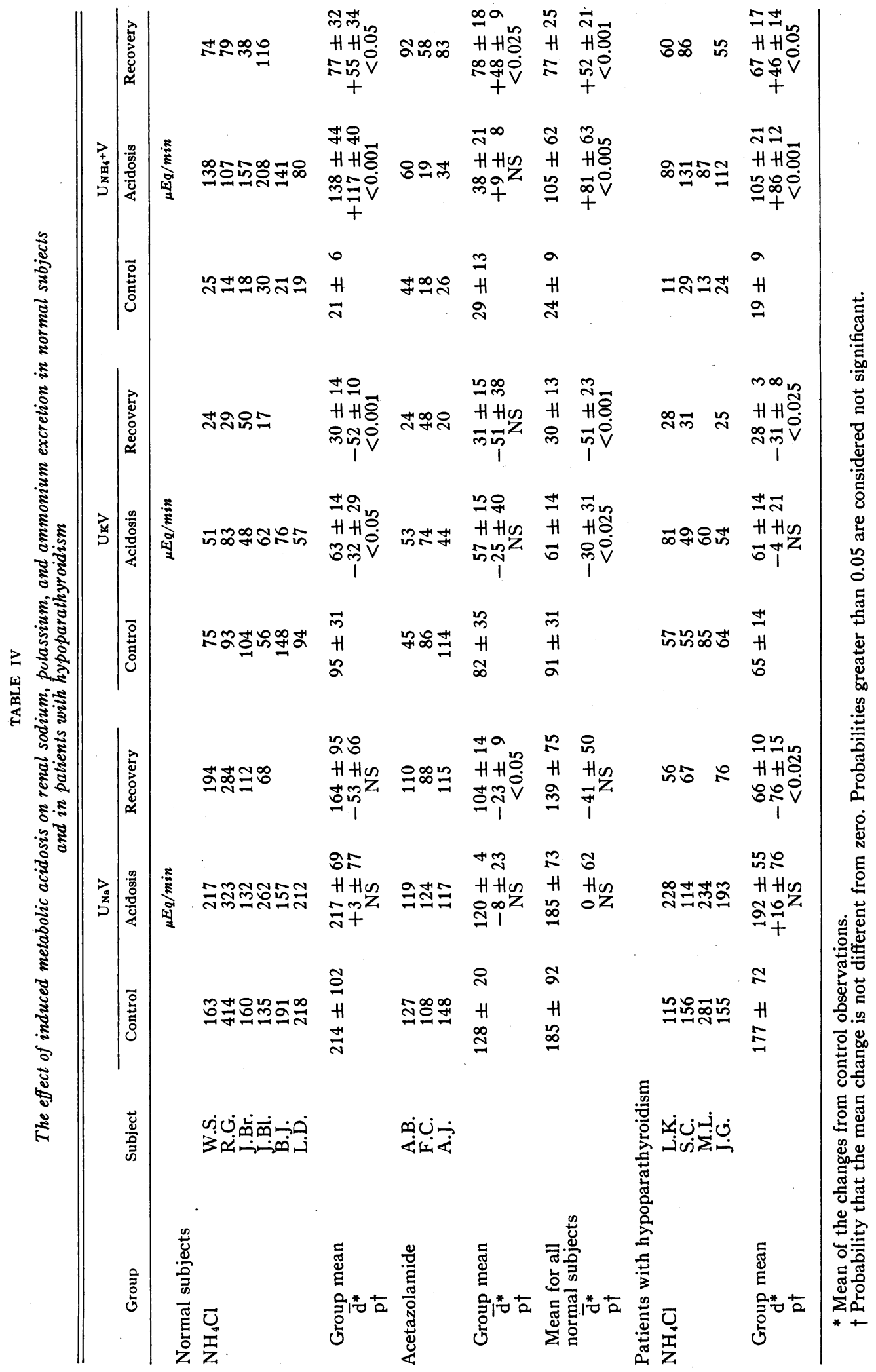




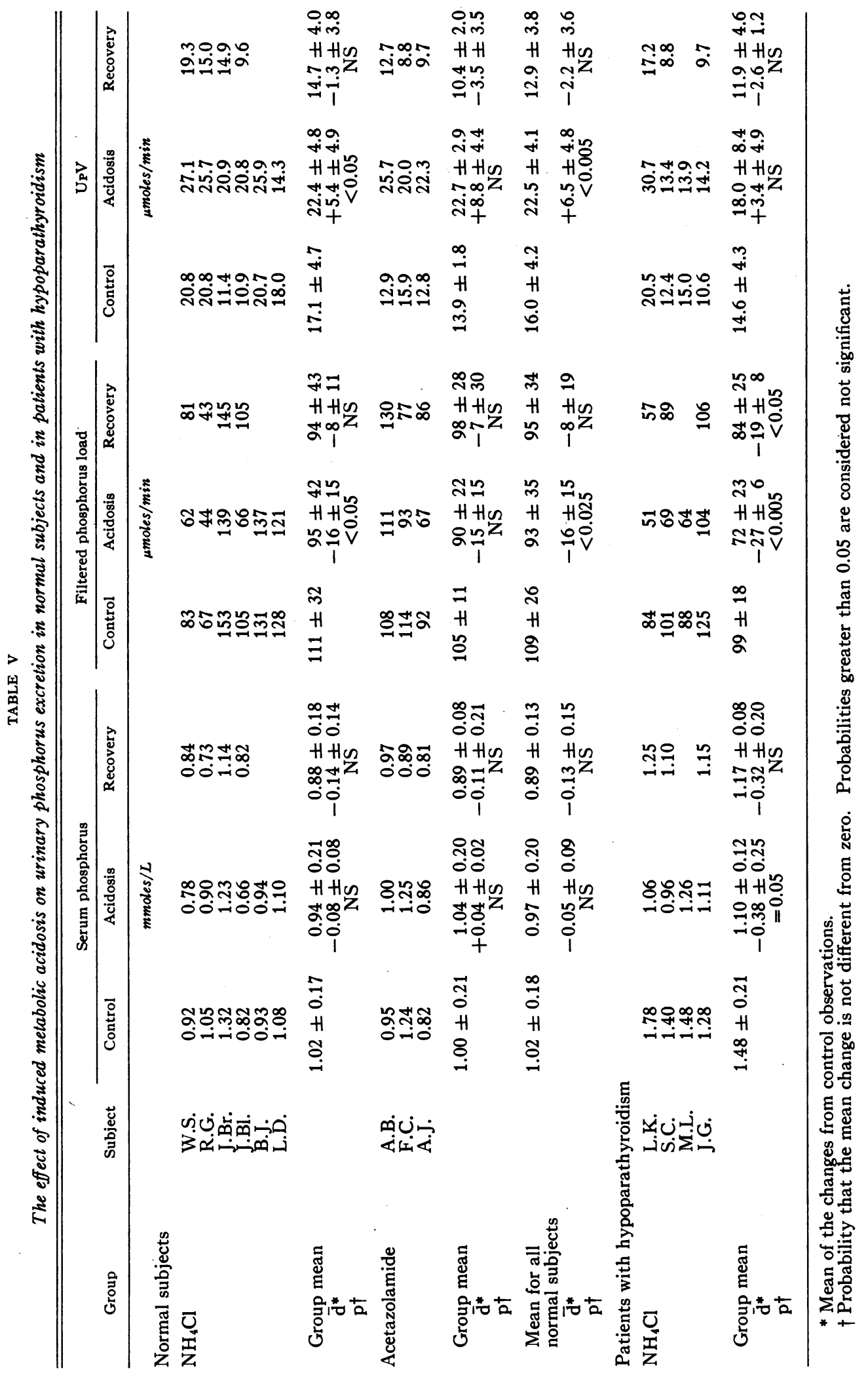


filtered load of calcium was sufficiently above control values to account for the continued increase in $\mathrm{U}_{\mathrm{Ca}} \mathrm{V}$. In the other three normal subjects, $\mathrm{U}_{\mathrm{Ca}} \mathrm{V}$ remained above control despite a reduction in the rate of calcium filtration.

$\mathrm{U}_{\mathrm{Ca}} \mathrm{V}$ also remained elevated in the three patients studied during recovery from acidosis, despite correction of blood $\left[\mathrm{H}^{+}\right]$and serum $\left[\mathrm{HCO}_{3}{ }^{-}\right]$to normal. In each of these patients, the filtered load of calcium had returned to or below control levels by this time.

Table IV gives the changes in $\mathrm{U}_{\mathrm{Na}} \mathrm{V}, \mathrm{U}_{\mathrm{K}} \mathrm{V}$, and $\mathrm{U}_{\mathrm{NH}_{4}}+\mathrm{V}$ during acidosis and during recovery for all studies. Serum sodium concentration remained normal and steady in all groups. Serum potassium concentration fell during acidosis and remained low during the recovery clearances in all studies. $\mathrm{U}_{\mathrm{Na}} \mathrm{V}$ was below control rates in six of the nine normal subjects during acidosis and in all seven of the studies during recovery. There was no correlation between the variable changes in $\mathrm{U}_{\mathrm{Na}} \mathrm{V}$ and the consistent increases in $\mathrm{U}_{\mathrm{Ca}} \mathrm{V}$ during acidosis. $U_{\mathbf{K}} \mathrm{V}$ fell in seven of the normal subjects during acidosis and in each of the seven recovery studies. As expected, $\mathrm{U}_{\mathrm{NH}_{4}} \mathrm{~V}$ rose significantly in each normal subject given $\mathrm{NH}_{4} \mathrm{Cl}$, whereas smaller rises occurred in the three normal subjects made acidotic by carbonic anhydrase inhibition (acetazolamide). $\mathrm{U}_{\mathrm{NH}_{4}+\mathrm{V}}$ fell, but remained above control when $\mathrm{NH}_{4} \mathrm{Cl}$ administration

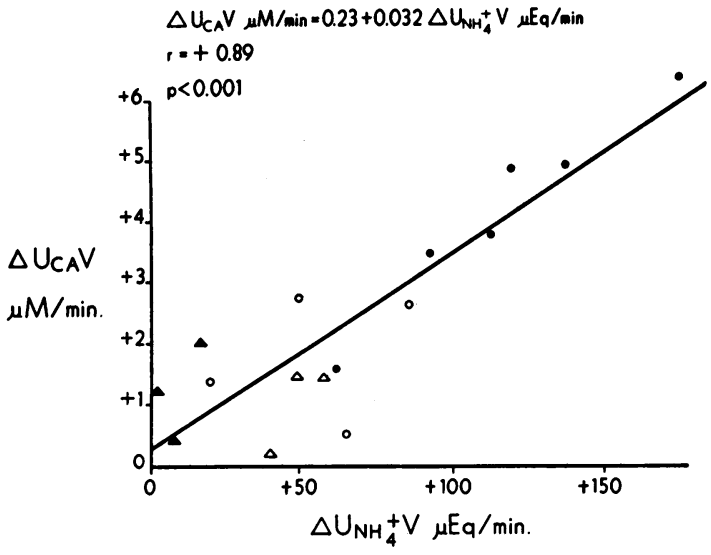

Fig. 1. Correlation betweEn changes in URINARy CALCIUM EXCRETION ( $\Delta \mathrm{U}_{\mathrm{Ca}} \mathrm{V}$ ) AND CHANGES IN URINARY AMMONIUM EXCRETION ( $\left.\Delta \mathrm{U}_{\mathrm{NH} 4+} \mathrm{V}\right)$ IN NORMAL SUBJECTS. $0=\mathrm{NH}_{4} \mathrm{Cl}$ acidosis, $\mathrm{O}=$ recovery from $\mathrm{NH}_{4} \mathrm{Cl}$ acidosis, $\Delta=$ acetazolamide acidosis, $\Delta=$ recovery from acetazolamide acidosis.

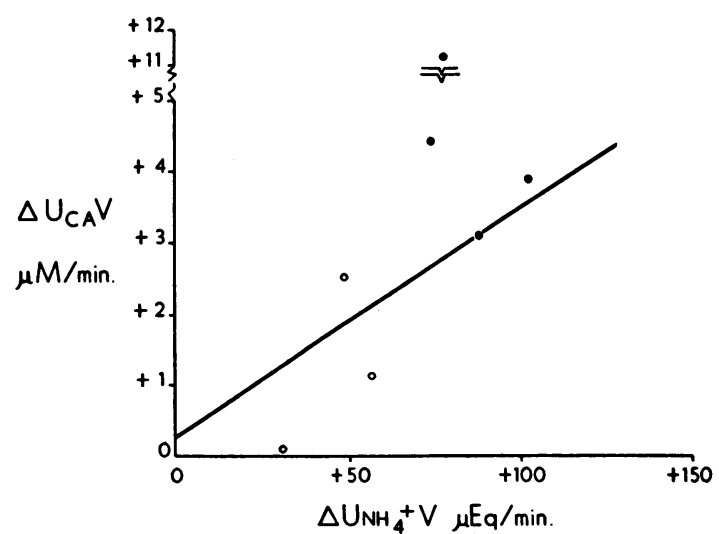

Fig. 2. Relationship Between ( $\left.\Delta \mathrm{U}_{\mathrm{Ca}} \mathrm{V}\right)$ and $\left(\Delta \mathrm{U}_{\mathrm{NH}_{4}+} \mathrm{V}\right)$ IN PATIENTS WITH HYPOPARATHYROIDISM. $0=\mathrm{NH}_{4} \mathrm{Cl}$ acidosis, $\mathrm{O}=$ recovery from $\mathrm{NH}_{4} \mathrm{Cl}$ acidosis. The solid line is the regression line for the normal subjects, which is included in this figure for comparison.

was stopped, and exceeded the values during acidosis when acetazolamide was stopped. The changes in $\mathrm{U}_{\mathrm{Na}} \mathrm{V}, \mathrm{U}_{\mathrm{K}} \mathrm{V}$, and $\mathrm{U}_{\mathrm{NH}_{4}+} \mathrm{V}$ in the patients were comparable to those of the normal subjects given $\mathrm{NH}_{4} \mathrm{Cl}$.

Figure 1 shows a striking correlation between the increments in renal ammonium and calcium excretion above control during the acidosis and recovery clearances in the normal subjects.

Figure 2 shows the same relationship in the patients with hypoparathyroidism.

Table $\mathrm{V}$ presents the effects of induced acidosis on serum phosphorus concentration and renal phosphorus excretion. Serum phosphorus concentration fell during acidosis in six of the seven normal subjects given $\mathrm{NH}_{4} \mathrm{Cl}$ and rose slightly in each of the three normal subjects given acetazolamide. Because of the reductions in glomerular filtration rate, the filtered phosphorus load fell in seven of the nine normal subjects during acidosis. Despite this, $U_{P} V$ rose in all of the normal subjects. In the recovery studies in normal subjects, none of the parameters of renal phosphorus turnover differed from control observations. The results in the patients with hypoparathyroidism again closely resembled those of the normal subjects given $\mathrm{NH}_{4} \mathrm{Cl}$.

\section{Discussion}

In the present renal clearance studies, each of nine normal subjects demonstrated an increase in 
$\mathrm{U}_{\mathrm{Ca}} \mathrm{V}$ above control rates when metabolic acidosis was induced by either increasing acid production by $\mathrm{NH}_{4} \mathrm{Cl}$ administration (six subjects) or inhibiting renal acid excretion by acetazolamide administration (three subjects). In eight of the nine normal subjects, the observed increases in $\mathrm{U}_{\mathrm{Ca}} \mathrm{V}$ occurred despite reduction in the rates of filtration of calcium. Whereas $\mathrm{UF}_{\mathrm{Ca}}$ rose during acidosis in each of the nine subjects, presumably because of decreased binding of calcium by serum proteins and a net increase in the rate of release of calcium from bone, inulin clearance fell to a greater extent and, thus, the calculated rate of filtration of calcium was reduced. We assume that the fall in glomerular filtration rate was due to extracellular fluid (ECF) volume depletion resulting from the initial diuretic effect of both $\mathrm{NH}_{4} \mathrm{Cl}$ and acetazolamide. Clearly, the increases in $\mathrm{U}_{\mathrm{Ca}} \mathrm{V}$ observed during acidosis in these subjects must have been due to decreased renal tubular calcium reabsorption.

$\mathrm{U}_{\mathrm{Ca}} \mathrm{V}$ remained elevated above control rates in each of the seven normal subjects studied again three days after $\mathrm{NH}_{4} \mathrm{Cl}$ or acetazolamide administration was stopped. Since blood $\left[\mathrm{H}^{+}\right]$and serum $\left[\mathrm{HCO}_{3}{ }^{-}\right]$had returned to control values in each subject by this time, it is clear that ECF acidosis could no longer be invoked as the cause of the augmented renal calcium excretion. However, we have shown previously (3) that during the recovery from induced metabolic acidosis blood $\left[\mathrm{H}^{+}\right]$and serum $\left[\mathrm{HCO}_{3}^{-}\right]$return to control levels before all of the retained acid has been eliminated from the body. Thus, it is quite conceivable that hydrogen ion concentration within cells (including those of the renal tubules) remained elevated at the time of the recovery clearances. In four of these seven recovery studies, the calculated rate of filtration of calcium had risen sufficiently to account for the persisting increase in $\mathrm{U}_{\mathrm{Ca}} \mathrm{V}$. This occurred because of increases in inulin clearances and, in some subjects, continued slight elevation of $\mathrm{UF}_{\mathrm{Ca}}$. In the remaining three studies, however, $\mathrm{U}_{\mathrm{Ca}} \mathrm{V}$ remained elevated despite rates of calcium filtration less than those of their control studies.

Although these results in normal subjects do not allow precise identification of the cause of decreased tubular calcium reabsorption during in- duced metabolic acidosis, we have considered several possibilities.

Walser (6) has shown that urinary calcium excretion rises when sodium excretion is augmented. This could not account for the results of our experiments, since, on the average, urinary sodium excretion was unchanged from control values during acidosis and somewhat below control values during the recovery studies. Furthermore, there was no correlation between the variable directional changes in $\mathrm{U}_{\mathrm{Na}} \mathrm{V}$ during acidosis and the consistent increases in $\mathrm{U}_{\mathrm{Ca}} \mathrm{V}$.

It is also unlikely that $\mathrm{U}_{\mathrm{Ca}} \mathrm{V}$ increased because of an increase in the rate of excretion of poorly reabsorbable anions capable of complexing calcium (7). Whereas urinary phosphorus excretion was increased during acidosis, it was not elevated above control rates during the recovery clearances, when $\mathrm{U}_{\mathrm{Ca}} \mathrm{V}$ remained elevated. Urinary sulfate and organic acid excretion did not increase significantly in our earlier balance studies in which acidosis was induced in a similar manner (3). In addition, the high urine flow rates maintained in all of the present clearance studies would have minimized, by dilution, any effects of complexing anions.

We carried out the studies in the four patients with hypoparathyroidism, two of whom were also hypothyroid, to determine whether the capacity to alter the secretion rate of parathyroid hormone, thyrocalcitonin, or both, was required for augmentation of $\mathrm{U}_{\mathrm{Ca}} \mathrm{V}$ during metabolic acidosis. We considered this possibility because the rise in ultrafilterable (and presumably ionized) calcium in the blood of the normal patients during acidosis could have altered the rates of secretion of these hormones. Parathyroid extract has been shown to augment directly calcium reabsorption at a distal tubular site in the dog (13), and thyrocalcitonin, while not yet known to alter tubular calcium reabsorption, produces phosphaturia in the rat (14). Since the response to metabolic acidosis in the normal subjects included both decreased tubular calcium reabsorption and decreased tubular phosphorus reabsorption, it seemed possible that these effects were mediated, respectively, by a decreased secretion of parathyroid hormone and an increased secretion of thyrocalcitonin in response to the rise in ultrafilterable (and ionized) calcium. The results in the four patients 
suggest that this was not the case. With the exception of the study during acidosis in patient L. K. (where the rate of calcium filtration rose sufficiently to account for the increase in $\mathrm{U}_{\mathrm{Ca}} \mathrm{V}$ ), the responses of the patients closely resembled those of the normal subjects.

Finally, since metabolic acidosis alters metabolic processes in renal tubular cells in other ways (15), it is possible that the observed decrease in calcium reabsorption during acidosis is also a direct effect on the tubule cells. A correlation between the increments in urinary ammonium and calcium excretion in response to induced acidosis was noted in both the normal subjects (Figure 1) and the patients (Figure 2).

Although in two of the three normal subjects given acetazolamide maximal $\mathrm{U}_{\mathrm{Ca}} \mathrm{V}$ occurred during the acidosis clearances while $\mathrm{U}_{\mathrm{NH}_{4}} \mathrm{~V}$ was higher during the recovery clearances, it is known that urinary ammonium excretion may underestimate total renal tubular ammonia production during carbonic anhydrase inhibition (16). Thus, stimulation of the metabolic processes involved in the tubular production of ammonia rather than urinary ammonium excretion per se may somehow impair renal tubular calcium reabsorption. Farquharson, Salter, Tibbetts, and Aub (1) also noted that changes in calcium and ammonium excretion were related in induced metabolic acidosis. Although they felt that calcium and ammonium excretion during acidosis were not directly interdependent, this will require further study.

\section{References}

1. Farquharson, R. F., W. T. Salter, D. M. Tibbetts, and J. C. Aub. Studies of calcium and phosphorus metabolism. XII. The effect of the ingestion of acid-producing substances. J. clin. Invest. 1931, 10, 221.

2. Sartorius, O. W., J. C. Roemmelt, and R. F. Pitts. The renal regulation of acid-base balance in man. IV. The nature of the renal compensations in ammonium chloride acidosis. J. clin. Invest. 1949, 28, 423.

3. Lemann, J., Jr., J. R. Litzow, and E. J. Lennon. The effects of chronic acid loads in normal man: further evidence for the participation of bone mineral in the defense against chronic metabolic acidosis. J. clin. Invest. 1966, 45, 1608.

4. Atchley, D. W., R. F. Loeb, D. W. Richards, Jr., E. M. Benedict, and M. E. Driscoll. On diabetic acidosis. A detailed study of electrolyte balances following the withdrawal and reestablishment of insulin therapy. J. clin. Invest. 1933, 12, 297.

5. Williamson, B. J., and S. Freeman. Effects of acute changes in acid-base balance on renal calcium excretion in dogs. Amer. J. Physiol. 1957, 191, 384.

6. Walser, M. Calcium clearance as a function of sodium clearance in the dog. Amer. J. Physiol. 1961, 200, 1099.

7. Walser, M. Ion association. VII. Dependence of calciuresis on natriuresis during sulfate infusion. Amer. J. Physiol. 1961, 201, 769.

8. Earley, L. E., and R. M. Friedler. Studies on the mechanism of natriuresis accompanying increased renal blood flow and its role in the renal response to extracellular volume expansion. J. clin. Invest. 1965, 44, 1857.

9. Davidson, W. D., and M. A. Sackner. Simplification of the anthrone method for the determination of inulin in clearance studies. J. Lab. clin. Med. 1963, 62, 351.

10. Toribara, T. Y., R. Terepka, and P. Dewey. The ultrafilterable calcium of human serum. I. Ultrafiltration methods and normal values. J. clin. Invest. $1957,36,738$.

11. Lennon, E. J., J. Lemann, Jr., and J. R. Litzow. The effect of diet and stool composition on the net external acid balance of normal subjects. J. clin. Invest. 1966, 45, 1601.

12. Snedecor, G. W. Statistical Methods, 5th ed. Ames, Iowa, Iowa State College Press, 1956, p. 45.

13. Widrow, S. H., and N. G. Levinsky. The effect of parathyroid extract on renal tubular calcium reabsorption in the dog. J. clin. Invest. 1962, 41, 2151.

14. Robinson, C. J., T. J. Martin, and I. MacIntyre. Phosphaturic effect of thyrocalcitonin. Lancet 1966, 2, 83.

15. Goodman, A. D., R. E. Fuisz, and G. F. Cahill, Jr. Renal gluconeogenesis in acidosis, alkalosis and potassium deficiency: its possible role in regulation of renal ammonia production. J. clin. Invest. 1966, 45, 612.

16. Owen, E. E., M. P. Tyor, J. F. Flanagan, and J. N. Berry. The kidney as a source of blood ammonia in patients with liver disease: the effect of acetazolamide. J. clin. Invest. 1960, 39, 288. 